\title{
Jean-Baptiste Charcot and Brazil
}

\author{
Jean-Baptiste Charcot e o Brasil
}

Hélio Afonso Ghizoni Teive ${ }^{1}$, Carlos Frederico Leite de Souza Lima², Plínio Marcos Garcia de Lima1, Francisco Manoel Branco Germiniani', Renato Puppi Munhoz ${ }^{3}$

\begin{abstract}
Jean-Baptiste Charcot, a neurologist from the famous Salpêtrière school and a renowned maritime explorer, visited Brazil twice. The first visit was in 1903, when the first French Antarctic expedition, traveling aboard the ship Français, made a very short stopover in Recife, in the state of Pernambuco. The second took place in 1908, during the famous voyage of the Pourquoi Pas? to the Antarctic, when Charcot and his crew stayed in the city of Rio de Janeiro for eight days.
\end{abstract}

Keywords: neurology, maritime, explorer, Antarctic, Brazil.

RESUMO

Jean-Baptiste Charcot, neurologista formado na famosa escola do hospital Salpêtrière, e famoso explorador marítimo, visitou o Brasil por duas vezes. A primeira em 1903, numa curta passagem, em Recife/Pernambuco, a bordo do navio Français, durante a primeira expedição francesa à antártica, e a segunda, em 1908, durante a famosa viagem do Pourquoi Pas? à Antártica, quando ele e sua tripulação permaneceram na cidade do Rio de Janeiro por oito dias.

Palavras-chave: neurologia, explorador, marítimo, Antártica, Brasil.

Professor Jean-Martin Charcot (1825-1893) is considered the first ever professor of neurology and the father of clinical neurology. During the $19^{\text {th }}$ century, the French School of Neurology was known worldwide and respected as a center of reference for physicians, many of whom visited Charcot and his service ${ }^{1,2,3,4,5}$. Professor Charcot had connections with Dom Pedro II, the Brazilian emperor, both socially and in the medical field. In fact, Dom Pedro II invited Professor Charcot several times to come to Brazil, but unfortunately these invitations were declined ${ }^{2,6}$. However, Professor Charcot's son, the neurologist and maritime explorer Jean-Baptiste Charcot, visited Brazil twice ${ }^{7,8}$. The aim of this manuscript is to review these visits, which occurred in 1903 and 1908.

\section{JEAN-BAPTISTE CHARCOT - THE MARITIME EXPLORER}

Jean-Baptiste Charcot (1867-1936) was a neurologist who trained at the Salpêtrière school under the supervision of Professor Charcot's pupils, particularly Bissaud, $2,3,4,5,7$, . However, after Professor Charcot's death, Jean-Baptiste
Charcot inherited a considerable sum and became a maritime explorer. Initially, he decided to explore the polar regions and first visited the Arctic, to which he made several expeditions, gaining an enviable reputation for scientific investigation $^{7,8}$. After these expeditions he took part in the project known as The French Antarctic Expedition and started his activities as a maritime explorer in the South Pole ${ }^{7,8}$. The first expedition to the Antarctic polar ice cap (1903-1905) traveled on the famous ship Français, and the second (1908-1910) on the Pourquoi Pas? After the first expedition, Jean-Baptiste Charcot became a true star and was known as Commander Charcot (Figure 1) ${ }^{7,8}$.

\section{THE FIRST VISIT TO BRAZIL}

The first French Antarctic expedition left Le Havre on August 27, 1903, aboard the ship Français. After a short stop at the Madeira islands, the Français arrived in Recife, in the state of Pernambuco, on October 20, 1903, with a crew of twenty-one including Commander Charcot. It was in fact a very short stop to replenish the water supply before the

\footnotetext{
${ }^{1}$ Serviço de Neurologia, Departamento de Clínica Médica, Hospital de Clínicas, Universidade Federal do Paraná, Curitiba PR, Brazil;

${ }^{2}$ Serviço de Neurologia, Hospital Universitário Oswaldo Cruz, Universidade Federal de Pernambuco, Recife PE, Brazil;

${ }^{3}$ Movement Disorders Centre, Toronto Western Hospital, University of Toronto, Toronto ON, Canada.

Correspondence: Hélio A. G. Teive; Rua General Carneiro,1103/102 Centro; 80060-150, Curitiba PR, Brasil. E-mail:hagteive@mps.com.br

Conflict of interest: There is no conflict of interest to declare.
}

Received 20 April 2014; Received in final form 03 May 2014; Accepted 23 May 2014. 


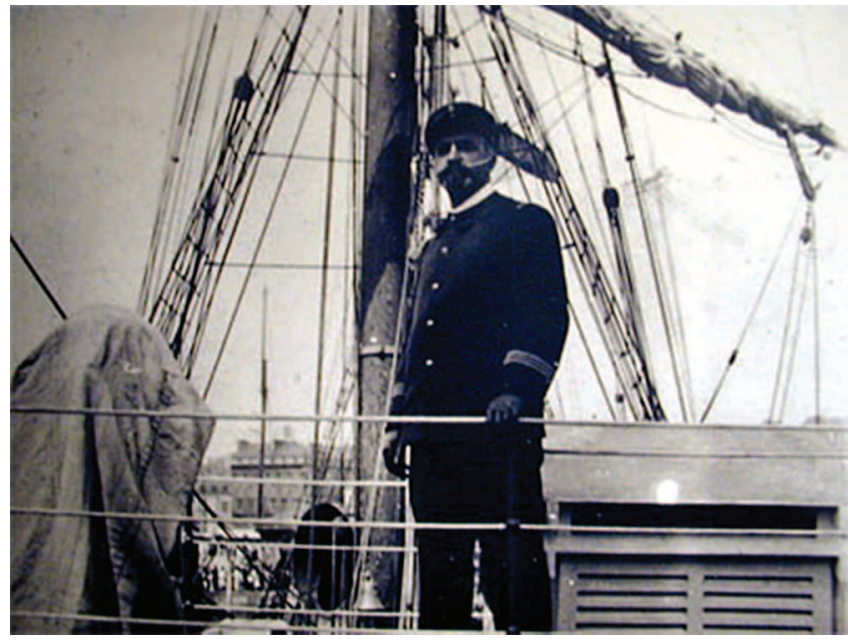

Figure 1. Jean-Baptiste Charcot (1867-1936). (Extracted from Google Images. Coolantartica.com)

onward journey to Buenos Aires. Commander Charcot and his crew were received by local authorities and left for Buenos Aires aboard the Français the same day. The newspaper Diário de Pernambuco, founded in 1825 and considered the first newspaper in continuous circulation in Latin America, published the news in its edition of October 20, 1903 (Figure 2).

\section{THE SECOND VISIT TO BRAZIL}

The second French Antarctic expedition left Le Havre on August 15, 1908, with a crew of twenty-two people aboard

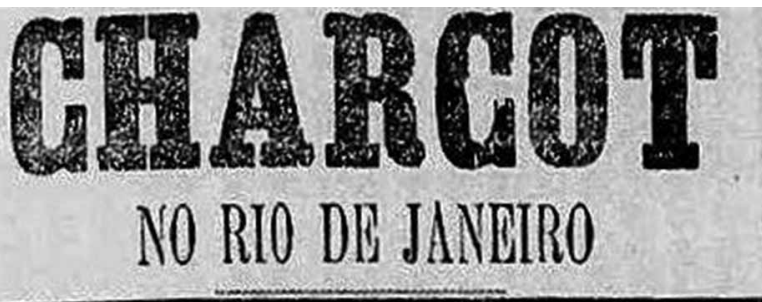

\section{A chegada do «Pour quoi pas ?*, que se dirige para o pólo sul - Charcot conta a sua viagem -0 «Pour quoi pas?»- o homem em quem o mundo pensa}

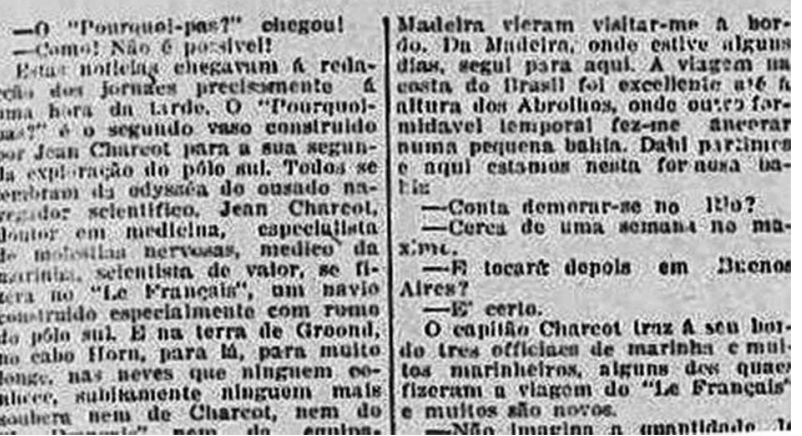

Figure 3. The Charcot Expedition - Rio de Janeiro, RJ, Brazil (Gazeta de Notícias, October, 13, 1908). (Extracted from Hemeroteca Digital Brasileira - hemerotecadigital.bn.br December, 26, 2013)

the Pourquoi Pas? The diary of the expedition to the South Pole was published as The voyage of the 'Pourquoi Pas?' in the Antarctic ${ }^{7,8}$. In this diary, Jean-Baptiste Charcot divided the trip into three parts: the first, covering the summer of

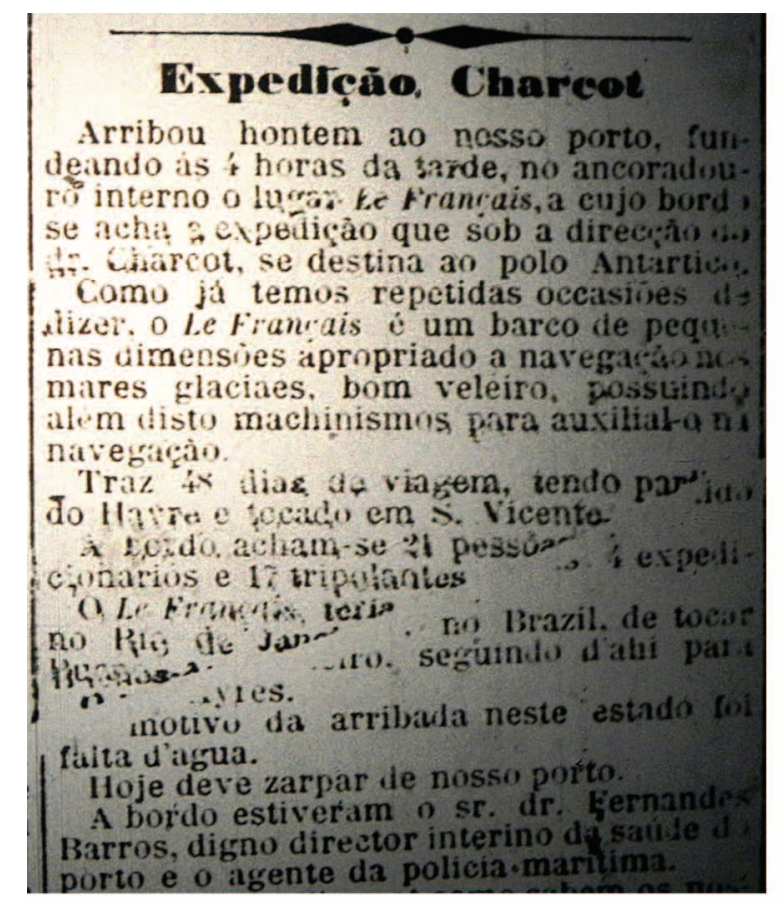

Yesterday at 4pm, Le Francais docked at the internal anchorage, on board of which is the expedition that, under the command of Dr. Charcot, is intended for Antartica. As we have repeatedly mentioned, Le Francais is a boat of smaller proportions, appropriate for navigation on glacial seas, a good sailing boat which has also engine mechanisms to aid in navigation.The boat docked 48 days after leaving Havre, reaching initially Sao Vicente. On board, a total 21 people, including 4 explorers and $17 \mathrm{crew}$ members. The Le Francais should have docked initially at Rio de Janeiro on its way to Buenos Aires. The reason for this change of plans was the shortage of water. Today, it is supposed to leave our port. Visiting the ship were Sr. Dr. Fernandes Barros, the honorable port's interim director of Health, and the agent of maritime police. The Charcot expedition, as known by our readers, is destined to support the explorer Nordenskiöld (Nils Otto Gustaf Nordenskjöld (December 6, 1869 - June 2, 1928, Finnish and Swedish geologist, geographer, and polar explorer), who is also been assisted by an Argentinean expedition. 
1908 and 1909, the second, the autumn, winter and spring of 1909, and the third, the summer of 1909 to the summer of $1910^{7,8}$. On October 12, 1908, the Pourquoi Pas? arrived in the city of Rio de Janeiro, where Commander Charcot and his crew were received by members of the Brazilian government and the French community, headed by the vice-consul, Mr. Charlat. (Figure 3) The Baron of Rio Branco, the Minister of Foreign Affairs, received the whole expedition at the Itamaraty Palace, and Admiral Alexandrino de Alencar, the Minister of the Marine, visited the Pourquoi Pas? Captain Barros Cobra gave the crew a special gift, a silk flag embroidered by his wife's own hands ${ }^{7,8}$. Commander Charcot and his crew stayed in Rio de Janeiro for eight days, enjoying the kindness and gifts of the Brazilian people, and then left for Buenos Aires on October 20, $1908^{7,8}$.

In conclusion, Professor Charcot's son, Jean-Baptiste Charcot, formerly a neurologist and later a famous maritime explorer, visited Brazil twice. First in 1903, on a very short stopover in Recife aboard Français, and the second time in 1908 aboard Pourquoi Pas? when he and his crew stayed for eight days in the city of Rio de Janeiro.

\section{References}

1. Goetz CG, Bonduelle M, Gelfand T. Charcot. Constructing Neurology. New York, Oxford University Press, 1995.

2. Bailey P. J-M. Charcot. 1825-1893. His Life- His Work, Georges Guillain. New York, Paul B. Hoeber, Inc, 1959.

3. Guinon G. Charcot Intime. Paris Medical, 1925:511-516.

4. Souques A. Charcot Intime. La Presse Medicale, Mai 27, 1925:693-698.

5. Bonduelle M. The intimate Charcot. Rev Neurol (Paris) 1994;150:524-528
6.

Teive HAG, Almeida SM, Arruda WO, Sá DS, Werneck LC. Charcot and Brazil. Arq Neuropsiquiatr 2001;59:295-299.

7. Teive HAG, Munhoz RP, Simões JC. Charcot's son, commander Jean-Baptiste Charcot: from neurology to "Porquoi Pas?" Arq Neuropsiquiatr 2012;70:305-307.

8. Charcot JB. The voyage of the "Why Not? The Journal of the second French South Polar Expedition, 1908-1910. (Translation by Philip Walsh). University of Toronto Library, The Musson Book Company Limited, 1980. 